\title{
Analysis Of Android-Based Online Message Gateway Towards The Use Of Plastic Bags
}

\author{
Muhammad Ali Sodik*, Dhea Maulina Salam, Sri Kardjati \\ Institut Ilmu Kesehatan STRADA Indonesia, Kediri, Indonesia \\ *alisodik2012@gmail.com
}

\begin{abstract}
Plastic bags is increasing with the development of technology, industry and population. Community dependence on plastic products is indeed very large. It is undeniable that there are many plastic based equipment that are sold at relatively cheap prices. Therefore socialization or education to reduce the use of plastic bags should be intensified. the researchers used an approach with the Android Based Online Message Gateway. The research design used was pre experimental design. With a population of 64 , simple random sampling technique so that a sample of 56 respondents. Using the Wilcoxon statistical test with a significance level of 0.05 . The results showed that the significance value of the attitude variable $0,000<0.05$ and the significant value of the action variable $0,000<0.05$. So, if $\mathrm{Ho}$ and $\mathrm{H} 1$ are rejected, then there is the influence of Android Based Online Message Gateway on Attitudes and Action in the Use of Plastic Bags
\end{abstract}

Keywords: Action, Attitudes, Plastic Bags 


\section{STRADA Jurnal Ilmiah Kesehatan}

DOI: $10.30994 /$ sjik.v9i2.407

ISSN: 2252-3847 (print); 2614-350X (online)

Vol.9 No.2 November 2020 Page. 1657-1664

\section{BACKGROUND}

High population growth raises various social problems. One of them is a pile of garbage. Pile of rubbish becomes a serious problem because it causes environmental pollution, health problems, makes the environment look dirty and clogs waterways causing floods (Wintoko, 2012).

The use of plastics and plastic-based goods is increasing with the development of technology, industry and also the population. In Indonesia, the need for plastic continues to increase until it increases an average of 200 tons per year. As a result of the increased use of plastic, plastic waste is also increasing. Based on the Ministry of Environment (KLH) assumption, every day the Indonesian population produces $0.8 \mathrm{~kg}$ of waste per person or a total of 189 thousand tons of waste per day. Of this amount $15 \%$ is in the form of plastic waste or a total of 28.4 thousand tons of plastic waste / day (Fahlevi, 2012).

Based on the observations of researchers as a committee of volleyball competition in Kelurahan Manisrengoo in commemoration of the 74th Indonesian Independence Day. Coincides on September 13-21 2019. Researchers got protests from several residents who competed in volleyball. Because it only provides gallon bottled mineral water, it does not provide plastic glass bottled mineral water which aims to reduce plastic waste. Coupled with almost all people using plastic bags in carrying anything, for example shopping at markets, supermarkets, and malls. Where often do shopping activities are housewives.

Based on its origin, plastic waste is divided into industrial plastic waste and household plastic waste. Industrial plastic waste originates from the plastics manufacturing industry as well as industries engaged in processing. Household plastic waste is produced related to daily human activities such as plastic packaging, food or beverage plastic containers (Syamsiro et al, 2013).

For completeness of research data, interviews were conducted during the preliminary study on 30 September - 06 October 2019. Obtained information from various sources. Among other than 10 residents of the Manisrenggo Village. 4 of them were garbage collection officers in the Kelurahan Manisrenggo. 4 garbage collection officers said the volume of plastic waste in each house tends to increase. RW 01 produces 1.5 garbage carts of garbage every day, while the other RW produces 1 garbage cart, with dominating plastic waste. And 6 residents of Kelurahan Manisrenggo also said that the volume of plastic waste in each home tends to increase. 6 residents said that they always use plastic bags given by the seller. 4 of them said that the plastic waste was thrown away and taken by the garbage collection officers. While 2 other sources said that some of the plastic waste was burned. The increase in plastic waste shows that awareness to reduce the use of plastic bags is still low.

Therefore, socialization or education to reduce the use of plastic bags should be intensified. For maximum education, it is necessary to use the appropriate method. Community dependence on plastic products is indeed very large. Ranging from household products, stationery, medical devices, building materials, etc. many are made from plastic. It is undeniable that there are many plastic-based equipment that are sold at relatively cheap prices, making it affordable for the community.

Based on the facts above, the researcher can determine the title of the Android-Based Online Message Gateway Analysis of the Use of Plastic Bags in PKK Women in Kelurahan Manisrenggo, Kediri City. 


\section{STRADA Jurnal Ilmiah Kesehatan}

DOI: $10.30994 /$ sjik.v9i2.407

ISSN: 2252-3847 (print); 2614-350X (online)

Vol.9 No.2 November 2020 Page. 1657-1664

\section{METHODS}

In this study using a pre-experimental research design in an observational way in which researchers observe or measure independent and dependent variables with the pre test post test design approach. The sample in this study was 56 respondents.

\section{RESULTS}

A. RESPONDENT CHARACTERISTICS

Table 1 Respondent Characteristic

\begin{tabular}{|c|c|c|c|}
\hline No & Characteristics & $\Sigma \mathbf{N}$ & $\Sigma \%$ \\
\hline \multirow{4}{*}{1} & Age (year) & & \\
\hline & $<35$ & 11 & 20 \\
\hline & $36-50$ & 31 & 55 \\
\hline & $>50$ & 14 & 25 \\
\hline \multirow{8}{*}{2} & Educatin & & \\
\hline & No Education & 4 & 2 \\
\hline & Elementary school & 7 & 4 \\
\hline & Junior high school & 27 & 15 \\
\hline & Senior high school & 43 & 24 \\
\hline & D3 & 5 & 3 \\
\hline & S1 & 12 & 7 \\
\hline & S2 & 2 & 1 \\
\hline \multirow{6}{*}{3} & Profession & & \\
\hline & PNS & 3 & 5 \\
\hline & Swasta & 4 & 7 \\
\hline & Enterpreneur & 14 & 25 \\
\hline & Housewife & 34 & 61 \\
\hline & etc & 1 & 2 \\
\hline
\end{tabular}

Table 2 The attitude in the use of plastic bags in PKK

\begin{tabular}{|c|c|c|c|c|}
\hline \multirow{2}{*}{ Attitude } & \multicolumn{2}{|c|}{ Pre Test } & \multicolumn{2}{c|}{ Post Test } \\
\cline { 2 - 5 } & $\mathrm{F}$ & $\%$ & $\mathrm{~F}$ & $\%$ \\
\hline Good & 18 & $32,1 \%$ & 49 & $87,5 \%$ \\
\hline Enough & 28 & $50,0 \%$ & 7 & $12,5 \%$ \\
\hline Less & 10 & $17,9 \%$ & 0 & $\%$ \\
\hline Total & 56 & $100 \%$ & 56 & $100 \%$ \\
\hline
\end{tabular}

Table 3 Behavior in the use of plastic bags in PKK

\begin{tabular}{|c|c|c|c|c|}
\hline \multirow{2}{*}{ Behavior } & \multicolumn{2}{|c|}{ Pre Test } & \multicolumn{2}{c|}{ Post Test } \\
\cline { 2 - 5 } & $\mathrm{F}$ & $\%$ & $\mathrm{~F}$ & $\%$ \\
\hline Good & 2 & $3,6 \%$ & 49 & $87,5 \%$ \\
\hline Enough & 17 & $30,4 \%$ & 7 & $12,5 \%$ \\
\hline Less & 37 & $66,1 \%$ & 0 & $\%$ \\
\hline Total & 56 & $100 \%$ & 56 & $100 \%$ \\
\hline
\end{tabular}




\section{STRADA Jurnal Ilmiah Kesehatan}

DOI: $10.30994 /$ sjik.v9i2.407

ISSN: 2252-3847 (print); 2614-350X (online)

Vol.9 No.2 November 2020 Page. 1657-1664

\section{B. STATISTIC TEST}

Table 4 Test Statistical Ranks with SPSS 18 For Windows

\begin{tabular}{|c|c|c|c|c|}
\hline & & N & $\begin{array}{c}\text { Mean } \\
\text { Rank }\end{array}$ & Sum of Rank \\
\hline \multirow{4}{*}{ Post Attitude - Pre Attitude } & Negative Rank & 2 & 14.00 & 28.00 \\
\cline { 2 - 5 } & Positive Rank & 34 & 18.76 & 638.00 \\
\cline { 2 - 5 } & Ties & 20 & & \\
\cline { 2 - 5 } Post Action - Pre Action & Total & 56 & & \\
\hline & Negative Rank & 0 & 00 & 00 \\
\cline { 2 - 5 } & Positive Rank & 50 & 25.00 & 1275.00 \\
\cline { 2 - 5 } & Ties & 6 & & \\
\cline { 2 - 5 } & Total & 56 & & \\
\cline { 2 - 5 } & & & \\
\hline
\end{tabular}

Source: Valid Data 2020

Based on table 4 shows 2 respondents experienced a decrease in attitude after Android-based Online Message Gateway. 34 respondents got an increase in attitude value after the Android-Based Online Message Gateway, and 20 respondents got the same attitude value before the Online Message Gateway. There was no decrease in respondent's action after Android-Based Online Message Gateway, 50 respondents received an increase in action value after Android-Based Online Message Gateway, and 6 respondents got the same action value before Android-Based Online Message Gateway. 


\section{STRADA Jurnal Ilmiah Kesehatan}

DOI: $10.30994 /$ sjik.v9i2.407

ISSN: 2252-3847 (print); 2614-350X (online)

Vol.9 No.2 November 2020 Page. 1657-1664

Table 5 Wilcoxon Statistical Tests with SPSS 18 For Windows

\begin{tabular}{|c|c|c|}
\hline & $\begin{array}{c}\text { Post Attitudes - Pre } \\
\text { Attitudes }\end{array}$ & Post Action -Pre Action \\
\hline$Z$ & $-5,064$ & $-6,349$ \\
Asymp. Sig (2-Tailled) & .000 & .000 \\
\hline
\end{tabular}

Source: Valid Data 2020

Based on table 5, the $\mathrm{Z}$ attitude value is $-5,064$ with $\mathrm{p}$ value (Asymp. Sig 2-Tailled) 0,000 . Because the sig ( 2 -Tailled) value of $0,000<0.05$ then rejects Ho and $\mathrm{H} 1$ are accepted, then there is an influence of Android-based Online Message Gateway on Attitudes in the use of plastic bags in PKK mothers in Kelurahan Manisrenggo, Kediri City. The $\mathrm{Z}$ action value is $-6,349$ with $p$ value (Asymp. Sig 2-Tailled) 0,000. Because the sig (2-Tailled) value of $0,000<0.05$ then rejects Ho and H1 are accepted, then there is an influence of Androidbased Online Message Gateway on Action in the use of plastic bags in PKK mothers in Kelurahan Manisrenggo, Kediri City.

\section{DISCUSSION}

\section{The attitude in the use of plastic bags in PKK women in Kelurahan Manisrenggo, Kediri City}

a. Attitude Before Android-Based Online Messsage Gateway

Based on the results of the study showed the attitude of PPK mothers before the Android-Based Online Message Gateway that out of 56 PKK mothers have good attitude in using plastic bags as many as 18 PKK mothers $(32.1 \%)$. PKK mothers have the attitude in using enough plastic bags as many as 28 PKK mothers $(50.0 \%)$. Whereas PKK mothers have the attitude in using less than 10 PKK mothers (17.9\%). Judging from the large number that shows a fairly good attitude, this can be interpreted that awareness in reducing the use of plastic bags for PKK mothers in Kelurahan Manisrenggo Kediri is still quite low.

Counseling is a non-formal education process to change the behavior of adults in order to have better knowledge, skills and attitudes (Marzuki, 2008).

b. Attitude After Android-Based Online Messsage Gateway

Based on the results of the study showed the attitude of PPK mothers after Android-Based Online Message Gateway that out of 56 PKK mothers have good attitude in using plastic bags as many as 49 PKK mothers (87.5\%). PKK mothers have the attitude in using enough plastic bags as many as 7 PKK mothers (12.5\%). Whereas none of the PKK mothers have the attitude in using less plastic bags $(0 \%)$. This can be interpreted that the awareness of PKK mothers in Kelurahan Manisrenggo Kediri increased, as seen from the increasing number of PKK mothers who showed good attitudes and the decreasing number of PKK mothers who showed less good attitudes.

Action in the use of plastic bags in PKK mothers in Kelurahan Manisrenggo, Kediri City

a. Action Before Android Based Online Messsage Gateway

Based on the results of the study showed the action of PPK mothers before Android-Based Online Message Gateway that out of 56 PKK mothers had good action in using plastic bags by 2 PKK mothers (3.6\%). PKK mothers have the action in using enough plastic bags as many as 17 PKK mothers (30.4\%). Whereas PKK mothers have the action in using less than 37 PKK mothers (66.1\%). Judging from the large number showing bad action, this can be interpreted that awareness in reducing the use of plastic bags for PKK mothers in Kelurahan Manisrenggo Kediri is still low. 


\section{STRADA Jurnal Ilmiah Kesehatan}

DOI: $10.30994 /$ sjik.v9i2.407

b. Action After Android Based Online Messsage Gateway

Based on the results of the study showed the action of PPK mothers after Android-Based Online Message Gateway that out of 56 PKK mothers have good action in using plastic bags as many as $42 \mathrm{PKK}$ mothers (75.0\%). PKK mothers have the action in using enough plastic bags as many as 12 PKK mothers (21.4\%). Whereas PKK mothers have the action in using less than 2 PKK mothers (3.6\%). This can be interpreted that the awareness of PKK mothers in Kelurahan Manisrenggo Kediri increased, as seen from the increasing number of PKK mothers who showed good action and the decreasing number of PKK mothers who showed bad action.

\section{Effect of Android-Based Online Message Gateway on the attitude in the use of PKK mothers' plastic bags in Kelurahan Manisrenggo, Kediri City}

Based on research shows that the good attitude of PKK mothers after Android-based Online Message Gateway is improved compared to before the Android-based Online Message Gateway. Based on the results of the analysis showed 2 respondents experienced a decrease in attitude after Android-based Online Message Gateway. 34 respondents got an increase in attitude value after the Android-Based Online Message Gateway, and 20 respondents got the same attitude value before the Online Message Gateway. Based on table 4.18 , the $\mathrm{Z}$ attitude value is $-5,064$ with $\mathrm{p}$ value (Asymp. Sig 2-Tailled) 0,000. Because the sig (2-Tailled) value of 0,000 is more than 0.05 , then the Ho and $\mathrm{H} 1$ rejections are accepted, so there is an influence of the Android-Based Online Message Gateway on Attitudes in the use of plastic bags in PKK mothers in the Kelurahan Manisrenggo, Kediri City.

According to (Elisa, 2017) Attitude is the regularity of feelings, thoughts of one's behavior in social interaction. And attitude is an evaluation of various aspects of the social world. Social psychology researchers place attitudes as important in social interactions, because attitudes can influence many things that are important in social interactions, because attitudes can affect many things about behavior and as a central issue that can affect a person's behavior.

\section{Effect of Android-Based Online Message Gateway on action in the use of PKK mothers' plastic bags in Kelurahan Manisrenggo, Kediri City}

Based on research shows that the good action of PKK mothers after Android-Based Online Message Gateway is increasing compared to before the Android-Based Online Message Gateway. Based on the results of the analysis showed there was no decrease in the value of respondents' action after the Android-Based Online Message Gateway, 50 respondents received an increase in the value of the action after the Android-Based Online Message Gateway, and 6 respondents received the same action value as before the AndroidBased Online Message Gateway. Based on table 4.18, the $Z$ action value is $-6,349$ with $p$ value (Asymp. Sig 2-Tailled) 0,000. Because the sig (2-Tailled) value of 0,000 is more than 0.05 , then reject Ho and $\mathrm{H} 1$ are accepted,

This is directly proportional to the research (Rarasati, 2019) which shows that the Zero Weste campaign influences the behavior of reducing the use of plastic bags.

Environmental health behavior is how a person responds to the environment, both the physical and social cultural environment and so on, so that the environment does not affect his health. In other words, how a person manages his environment so that it does not interfere with one's own health, family or community (Notoatmodjo, 2007). 


\section{STRADA Jurnal Ilmiah Kesehatan}

DOI: $10.30994 /$ sjik.v9i2.407

ISSN: 2252-3847 (print); 2614-350X (online)

Vol.9 No.2 November 2020 Page. 1657-1664

\section{CONCLUSION}

Before Android-Based Online Message Gateways, 18 PKK women in Kelurahan Manisrenggo, Kediri City (32.1\%) had a good attitude in using plastic bags. After the Android-Based Online Message Gateway on PKK mothers in Kelurahan Manisrenggo, Kediri City who had a good attitude in using plastic bags increased, that was 49 PKK mothers $(87.5 \%)$. Before the Android-Based Online Message Gateway as many as 2 PKK mothers in Kelurahan Manisrenggo, Kediri City (3.6\%) had good action in using plastic bags. After the Android-Based Online Message Gateway on PKK mothers in Kelurahan Manisrenggo, Kediri City, which had good action in using plastic bags, there were 42 PKK mothers (75.0\%). There is an influence of Android-Based Online Message Gateway on attitudes and action in the use of plastic bags in PKK mothers in Kelurahan Manisrenggo, Kediri City

\section{REFERENCES}

A. Wawan dan Dewi M. (Yogyakarta). Teori dan Pengukuran Pengetahuan, Sikap, Perilaku Manusia. Nuha.

Ahmann, D and Dorgan. (2007). Bioenginering for Polluton Prevention Though Development of Biobased Energy and Materials State of the Science Report. EPA/600/R-07/028, 76-78.

Arikunto, Suharsimi. (2014). Prosedur Penelitian Suatu Pendekatan Praktik. Jakarta: Rineka Cipta.

Azwar. (2011). Sikap Manusia Teori dan Pengukurannya. Yogyakarta: Pustaka Pelajar.

Azwar, Saifudin. (2013). Metode Penelitian. Yogyakarta: Pustaka Pelajar.

Eliza. (2017). Sikap dan Faktor yang Berpengaruh Buku Ajar Keperawatan. Jakarta: Salemba Medika.

Fahlevi, M.R. (2012). Sampah Plastik. Retrieved from http://rizalfahlevi.blogspot.com/2012/01/tw it-sampah-plastik.html

Farelya, Gita dan Nurrobikha. (2015). Etikolegal dalam Pelayanan Kebidanan. Yogyakarta: Deepublish.

Hidayat, A. Alimul. (2010). Metode Penelitian Kesehatan Paradigma Kuantitatif. Jakarta: Heat Books.

Kadir. (2012). Pemanfaatan Sampah Plastik Sebagai Sumber Bahan Bakar Cair. Dinamika Jurnal Ilmiah Tehnik Mesin, 3(2), 223-228.

Koswara. (2006). Bahaya Dibalik Kemasan Plastik. Retrieved from ebookpangan.com

Marzuki. (2008). Paradigma Baru Penyuluhan Pembangunan Dalam Pemberdayyan Masyarakat.

Mulyasa. (2011). Buku Ajar Teori Dasasr Pendidikan. Yogyakarta: Gava Medika.

Notoadmodjo, Soekidjo. (2007). Promosi Kesehatan dan Ilmu Perilaku. Jakarta: Rineka Cipta.

Notoadmodjo, Soekidjo. (2010). Ilmu Perilaku Kesehatan. Jakarta: Rineka Cipta.

Notoadmodjo, Soekidjo. (2012). Kesehatan Masyarakat Ilmu dan Seni. Jakarta: Rineka Cipta.

Nursalam. (2008). Pendekatan Praktis Metodologi Riset Kesehatan. Jakarta: Salemba Medika.

Nursalam. (2010). Konsep dan Penerapan Metodologi Penelitian Ilmu Keperawatan. Jakarta: Salemba Medika. 


\section{STRADA Jurnal Ilmiah Kesehatan}

DOI: $10.30994 /$ sjik.v9i2.407

ISSN: 2252-3847 (print); 2614-350X (online)

Vol.9 No.2 November 2020 Page. 1657-1664

Rahmadini, Rani. DKK. (2014, Oktober). Perbedaan Metode Penyuluhan Tentang Sampah Terhadap Pengetahuan Ibu Rumah Tangga Dalam Pengolahan Sampah Rumah Tangga di Kampung Pulo, Jakarta Timur. BIOSFER, Vol VII No 2.

Rarasati, Randyani. (2019). Pengaruh Terpaan Berita Satwa Laut yang Mati Akibat Sampah

Plastik dan Kampanye. Departemen Ilmu Komunikasi Fakultas Ilmu Sosial dan Ilmu

Politik Universitas Diponegoro, 8.

Sariana, Erna. (2018, Desember). Efektivitas Intervensi Pendidikan Kesehatan Terhadap Tingkat Pengetahuan Dan Sikap Tentang Pemilahan Sampah Pada Siswa Sekolah Dasar Negeri Di Kota Serang. ARKESMAS, Vol 3 No 2.

Sugiyono. (2010). metode Penelitian Kuantitatif Kualitatif. Bandung: Alfabeta.

Sugiyono. (2011). Metode Penelitian Kombinasi (Mixed Methods). Bandung: Alfabeta.

Susilowati. (2016). Gizi dalam Daur Kehidupan. bandung: Refika Aditama.

Syamsiro M, Saptoadi H, Norsujianto T, Novitasari P, Cheng S, Alimuddin Z, Yoshikawaa K. (2013). Fuel Oil Production from Municipal Plastic Westes in Sequential Pyrolysis and Catalytic Reforming Reactors. Energy Procedia, 47.

Victor. (2012, 2). Retrieved from Sejarah dan Perkembangan Plastk: http://victor welding blogspot.com/2012/02/sejarah-danperlembangan-plastik.Html

Wintoko, Bambang. (2012). Panduan Praktis Mendirikan Bank Sampah dan Kemapanan Finansial. Yogyakarta: Pustaka Baru Press. 